\title{
What do Medical Students Need to Learn in Their English Classes?
}

\author{
Giti Karimkhanlouei \\ Zanjan Medical University, Iran \\ Email: ghiti@zums.ac.ir
}

\begin{abstract}
Our long term goal as teachers is to match the content of the courses to the students' needs. The students of medicine are not so positive about the content of their course. Due to the different levels of the students' backgrounds in English classes or ESP classes and regarding the obstacles the instructors are encountered with in what to teach so as to meet the expectations of ESP students a needs analysis can be so helpful, so as to channel the instruction toward the learners' enthusiasm and interest and to make the output worthy A needs analysis assessment is a very beneficial step to reach this goal. The overall aim of the NA is the identification of elements which will lend themselves to training (Gillet 1973). This research is an endeavor to find out about the needs of the students of medicine in mastering different skills of language in the process of academic context.To do this research students were asked to ill out a questionnaire of needs analysis . The findings revealed that most of the students attached priority to mastering basic skills. The results of this research can be helpful in making decisions on what to teach to such students. By means of carrying out such a research instructors can be aware of the particular needs and perceptions of their subjects in the classroom which otherwise may remain hidden from the sight of those involved in curriculum planning on one hand and assumed instructors on the other hand.
\end{abstract}

Index Terms—needs analysis, English for specific purposes ( ESP), medical students

\section{BACKGROUND/INTRODUCTION}

EMS (English for Medical Students) programs have been developed without conducting a systematic needs analysis from both the students' and instructors' point of view. On the importance of needs analysis there are myriad of viewpoints. Widdowson (1981) states that "if a group of learners' needs for a language can be accurately specified, then this specification can be used to determine the content of a language program that will meet these needs."Hutchinson \&Waters (1992) argue that if learners, sponsors, and teachers know why learners need English, that awareness will have an influence on what will be accepted as reasonable content in the language course and what potential can be exploited. The ESP approach uses the needs analysis framework as the main tool to define learners' needs in a specific field because the awareness is more recognizable in a specific target situation representing a "real-life-situation". Witkin and Altschuld (1995) define needs analysis as a systematic set of procedures undertaken for the purpose of setting priorities and making decisions about programs or organizational improvement and allocation of resources. These statements are a means to channel our thought toward the importance of needs analysis and how it can help b teachers, curriculum designers and students to reach the goal of language learning in academic contexts as well as in any other settings.

English teachers in academic levels (EAP) are responsible to help students develop the kind of English proficiency that will lead to success in their academic life.

In his research on Nursing students English language proficiency,Bosher (2002) conducted a needs analysis study to account for the perceptions of these students on their need students in English classes. The findings indicated that communicating with clients and colleagues in the clinical setting were the major areas of difficulty. Al-Busaidi (2003) investigated academic English, Almulhim (2001) and Al-Bazzaz (1994) looked at business English, and Al27 Gorashi (1988) investigated military English needs. However, very rare studies have considered widely and specifically the English language needs of medical students.

A major objective of the NA $\mathrm{n}$ this study is to establish a basis concerning the usefulness and applicabiliy of English by students in the academic situation. Specifically, information gathered the areas of interests and also the areas of difficulty The project aimed to assess the students' language requirements in academic situations

1. What are medical students' perceptions of their language needs in relation to the tasks they must perform in the university setting?

2. What specific language difficulties do medical students perceive themselves to have?

\section{Methodology}

The subjects of this study were 41 medical students of the Faculty of Medicine, Zanjan University who were native Persian speakers with an average age of between 19-21 years. All of them had passed the same national University 
General English or ESP as compulsory courses language of the university which ware required in order to enroll in the more advances ESP courses of the Faculty of Medicine

The objective was to gather basic, general information about the medical students' language needs. Furthermore, in development of the questionnaire some faculties were interviewed for their experiences.

To devise the instrument, a pilot study was done. The subjects of the pilot study were selected from the same pool as the participants of the main study.

A way to check the construct validity of a test or a questionnaire is to use the specialist's opinion or some informants' views. (Aldeson 1990b and 1990c) uses the judges in the examining of constructs of reading skills. Selinker uses specialists in understanding validity of a questionnaire.

To make sure that the items of the questionnaire do test, in fact, what they should, i.e., the questionnaire has construct validity, the questionnaire was put into judgment. In the first judgment test items were judged from the componential point of view.

In this test three university professors holding a $\mathrm{PhD}$ degree in the field of methodology in medical sciences as well as TEFL and therefore experts in this field were selected to judge the items. Although the items were sought to be very close together in nature, they were judged to be different enough to be classifiable into different categories.

The pilot student questionnaire took 20 minutes to be completed. This questionnaire was developed by Victoria Chan (2008) and has been used by a number of researchers. The reliability coefficient was estimated and the alpha in this pilot study was 0.83 with 7 cases. This alpha level was satisfactory to follow the study and to do the main administration.

Each section of the questionnaire served a unique purpose. The questionnaire was translated into Persian and as mentioned after a pilot administration it was administered to 25 students ( 21 females and 4 males). It focused on four aspects as follows:

1. How do you rate the importance of learning each of the subjects as related to four language skills including reading, writing, speaking and listening.

2. Which one of the four major English skills is the most important for success in your other subjects in the college?

3. How important are these tasks in English for your other subjects?

4. How do you evaluate your abilities and knowledge of English in the areas including Reading, Writing, Speaking, Listening, Grammar, General vocabulary and Medical vocabulary. The answers were rated on a six point Likert scale from the very important to unimportant on five point Likert scale but they were constricted to three points to make a facility in the analysis.

\section{RESUlts}

As was mentioned before the questionnaire was divided into four parts. Questions in part one included importance of skills. This part of the questionnaire was constructed regarding the four main language skills. The first skill concerned with reading skill and it was divided into different categories as follows:

a. newspapers b. Journals c. academic texts d. lecture handouts e. reference books f: reading materials on the interest.

As Table 1 demonstrates, In this part $61 \%$ selected reading handouts and $60 \%$ selected reading materials on the Internet as the most important. However, the whole ratings did not show a significant difference, and this can be an indication that they totally considered reading skill as an important skill to master.

A. Part 1: How do You Rate the Importance of Learning Each of the Subjects as Related to Four Language Skills?

TABLE 1:

READING SKILL

\begin{tabular}{|c|c|c|c|}
\hline Reading skill & $\begin{array}{l}\text { A little important } \\
\text { Fre. } \\
\%\end{array}$ & $\begin{array}{l}\text { important } \\
\text { Fre. } \\
\%\end{array}$ & $\begin{array}{l}\text { Very important } \\
\text { Fre. } \\
\%\end{array}$ \\
\hline Newspapers & $\begin{array}{l}10 \\
23.3 \%\end{array}$ & $\begin{array}{l}17 \\
39.5 \%\end{array}$ & $\begin{array}{l}16 \\
37.2 \%\end{array}$ \\
\hline Journals & $\begin{array}{l}8 \\
19.5 \% \\
\end{array}$ & $\begin{array}{l}17 \\
41.5 \%\end{array}$ & $\begin{array}{l}16 \\
39 \% \\
\end{array}$ \\
\hline Academic texts & $\begin{array}{l}7 \\
16.7 \%\end{array}$ & $\begin{array}{l}14 \\
33.3 \%\end{array}$ & $\begin{array}{l}21 \\
50 \%\end{array}$ \\
\hline Lecture handouts & $\begin{array}{l}20 \\
50 \%\end{array}$ & $\begin{array}{l}6 \\
15 \%\end{array}$ & $\begin{array}{l}14 \\
35 \%\end{array}$ \\
\hline Reference books & $\begin{array}{l}10 \\
24.4 \%\end{array}$ & $\begin{array}{l}6 \\
14.6 \%\end{array}$ & $\begin{array}{l}25 \\
61 \%\end{array}$ \\
\hline $\begin{array}{l}\text { Reading materials on the } \\
\text { internet }\end{array}$ & $\begin{array}{l}8 \\
20 \%\end{array}$ & $\begin{array}{l}8 \\
20 \%\end{array}$ & $\begin{array}{l}24 \\
60 \%\end{array}$ \\
\hline
\end{tabular}

To find out about the importance of learning language skills, the second skill under consideration was listening skill. This skill similar to the reading skill was divided into different subsections as follows. 
Listen to: a. to a radio b. to the television programs c. films d. course lectures e. materials/seminars f. class discussions

TABLE 2.

LISTENING SKILLS

\begin{tabular}{|l|l|l|l|}
\hline Listening skill & $\begin{array}{l}\text { A little important } \\
\text { Fre. }\end{array}$ & $\begin{array}{l}\text { important } \\
\text { Fre. }\end{array}$ & $\begin{array}{l}\text { Very important } \\
\text { Fre. \% }\end{array}$ \\
\hline Radio & 13 & 10 & \\
\hline TV programs & $32.5 \%$ & $25 \%$ & 17 \\
& 2 & 12 & $42.5 \%$ \\
\hline Films & $5 \%$ & $30 \%$ & 26 \\
& 4 & 9 & $65 \%$ \\
\hline Course lectures & $10.3 \%$ & $23.1 \%$ & 26 \\
& 9 & 6 & $66.7 \%$ \\
\hline Seminars & $22 \%$ & $14.6 \%$ & 26 \\
& 8 & 7 & $63.4 \%$ \\
\hline Classroom discussions & $25.5 \%$ & $22.6 \%$ & 16 \\
& 9 & 7 & $51.6 \%$ \\
\hline
\end{tabular}

As the table above clarifies, in listening skill films (66.7\%), TV programs (65\%) and course lectures $(63.4 \%)$ were rated as the most important ones. This finding could be justified if we assume that in the world of today majority of knowledge is gained through audiovisual means and students specify less of their time for listening to radio. Furthermore, since their classes are usually handled in English language on one hand, and they have to take part in monthly Journal clubs, this fact would offer good reasons for why they have attributed weight to course lectures.

As above, the speaking skill was divided into some areas including; a. in-class discussions; b. conferences; c. seminars; d. at presentations

TABLE 3.

SPEAKING SKILL

\begin{tabular}{|l|l|l|l|}
\hline Speaking skill & $\begin{array}{l}\text { A little important } \\
\text { Fre. } \\
\mathbf{\%}\end{array}$ & $\begin{array}{l}\text { important } \\
\text { Fre. } \\
\mathbf{\%}\end{array}$ & $\begin{array}{l}\text { Very important } \\
\text { Fre. } \\
\mathbf{\%}\end{array}$ \\
\hline In-class discussions & 10 & 6 & 19 \\
& $28.6 \%$ & $17.1 \%$ & $54.3 \%$ \\
\hline Conferences & 12 & 10 & 14 \\
& $33.3 \%$ & $27.8 \%$ & $38.3 \%$ \\
\hline Seminars & 11 & 11 & 13 \\
& $31.4 \%$ & $31.4 \%$ & $37.1 \%$ \\
\hline presentations & 10 & 10 & 16 \\
& $27.8 \%$ & $27.8 \%$ & $44.4 \%$ \\
\hline
\end{tabular}

A close consideration reflects the idea that they attached much importance to in- class discussions (54.3\%) among the other areas. This may be due to the fact that they feel a need to be able to talk and involve themselves in classroom discussions. As speaking in seminars is concerned, it has not attracted much attention (37.1\%). The reason may be that they have not still perceived this need to take an active role for speaking in seminars and for taking part in public or scientific presentations.

The other skill which was judged for its importance from students' point of view was writing skill. It was divided into subcategories including a. letters; c. course assignments; d. field reports; e. email messages; f. The internet; g. notes; h. exam papers 
TABLE 4.

WRITING SKILL

\begin{tabular}{|c|c|c|c|}
\hline Writing skill & $\begin{array}{l}\text { A little important } \\
\text { Fre. } \\
\%\end{array}$ & $\begin{array}{l}\text { important } \\
\text { Fre. } \\
\%\end{array}$ & $\begin{array}{l}\text { Very important } \\
\text { Fre. } \\
\%\end{array}$ \\
\hline Letters & $\begin{array}{l}9 \\
26.5 \%\end{array}$ & $\begin{array}{l}7 \\
20.6 \%\end{array}$ & $\begin{array}{l}18 \\
52.9 \%\end{array}$ \\
\hline Course assignments & $\begin{array}{l}7 \\
21.5 \%\end{array}$ & $\begin{array}{l}6 \\
18.2 \%\end{array}$ & $\begin{array}{l}20 \\
60.0 \%\end{array}$ \\
\hline Field Reports & $\begin{array}{ll}13 \\
38.2 \%\end{array}$ & $\begin{array}{l}8 \\
23.5 \%\end{array}$ & $\begin{array}{l}13 \\
38.2 \%\end{array}$ \\
\hline Email messages & $\begin{array}{l}6 \\
17.6 \% \\
\end{array}$ & $\begin{array}{l}5 \\
14.7 \% \\
\end{array}$ & $\begin{array}{l}23 \\
67.6 \% \\
\end{array}$ \\
\hline On the Internet & $\begin{array}{l}5 \\
14.3 \% \\
\end{array}$ & $\begin{array}{l}5 \\
14.3 \% \\
\end{array}$ & $\begin{array}{l}25 \\
71.4 \% \\
\end{array}$ \\
\hline Notes & $\begin{array}{l}13 \\
39.4 \% \\
\end{array}$ & $\begin{array}{l}5 \\
15.2 \% \\
\end{array}$ & $\begin{array}{l}15 \\
45.5 \% \\
\end{array}$ \\
\hline Exam papers & $\begin{array}{l}8 \\
22.9 \% \\
\end{array}$ & $\begin{array}{l}7 \\
20 \% \\
\end{array}$ & $\begin{array}{l}20 \\
57.1 \% \\
\end{array}$ \\
\hline
\end{tabular}

The most important scopes they needed writing skill for were for communication on the Internet (71.4\%), email messages $(67.6 \%)$ and course assignments $(60 \%)$. This finding is justified by the fact that in the world of today, our students pass much of their time of communication through the Internet. The subcategory of field reports which was marked as the least important (38.2\%) may be because of the fact that they did not have to write their clinical or lab reports in English language.

\section{B. Part 2 of the Questionnaire}

The second part of the questionnaire of needs analysis asked for ranking of the language skills which was the most important for success in their other subjects in the college. This part included four main skills of reading comprehension, listening, speaking and writing

TABLE 5:

RANKING OF THE LANGUAGE SKILLS

\begin{tabular}{|l|l|l|l|}
\hline \multicolumn{2}{l}{ Rkills which are more } \\
$\begin{array}{l}\text { important as related to success } \\
\text { in the students' subjects }\end{array}$ & $\begin{array}{l}\text { A little important } \\
\text { Fre. \% }\end{array}$ & $\begin{array}{l}\text { Important } \\
\text { Fre. \% }\end{array}$ & $\begin{array}{l}\text { Very important } \\
\text { Fre. \% }\end{array}$ \\
\hline Reading comprehension & 4 & 10 & 23 \\
& $10.8 \%$ & $27 \%$ & $62.2 \%$ \\
\hline Listening & 2 & 16 & 19 \\
& $5.4 \%$ & $43.6 \%$ & $51.4 \%$ \\
\hline Speaking & 3 & 4 & 30 \\
& $8.1 \%$ & $10.2 \%$ & $81.1 \%$ \\
\hline writing & 24 & 1 & 12 \\
& $64.9 \%$ & $2.7 \%$ & $32.4 \%$ \\
\hline
\end{tabular}

It was interesting to learn that the subjects of this study attached extreme importance to speaking skill (81.1\%) and then reading skill $(62.2 \%)$. This may be due to the specific circumstances in their classroom, where they have to talk out their ideas. Furthermore, the second priority of them which was attached to reading skill is deemed to be a selfsupporting point, due to the fact that they have to study their original textbooks written in English language.

\section{Part 3 of the Questionnaire:}

This part of the questionnaire focused on the level of importance of the tasks in English for their other subjects. The tasks were subdivided as follows;

Reading:

Textbooks -Technical articles in journals- Manuscripts-Texts on the Internet

\section{Writing}

Lab reports-Assignments-Taking notes in lectures-Answering questions related to the part of the textbook

\section{Listening \& Speaking}

Following lectures-Following question/ answer sessions in class-Listening to spoken presentations-Participating in discussions-Asking questions in class- spoken presentations

As to the reading skills, the tasks of reading textbooks and reading articles on the Internet were judged to be equally very important (46.3\%).However; the task of reading manuscripts did not attract much attention (24.4\%). This may be due to the fact that it may rarely occur that they read manuscripts in English.

Regarding writing, none of the tasks received considerable priority. An examination of table 6 reveals that totally they considered tasks under writing skill as not very important.

Furthermore, in listening and speaking they indicated majority of them indicated that the tasks of classroom discussions $(56.1 \%)$ and asking questions in class $(51.2 \%)$ were very important among others. 
TABLE 6.

IMPORTANCE OF THE SKILLS AS RELATED TO OTHER SUBJECTS?

\begin{tabular}{|c|c|c|c|}
\hline $\begin{array}{l}\text { Importance of the tasks related to } \\
\text { other subjects }\end{array}$ & $\begin{array}{l}\text { A little important } \\
\text { Fre. } \%\end{array}$ & $\begin{array}{l}\text { Important } \\
\text { Fre. } \\
\%\end{array}$ & $\begin{array}{l}\text { Very important } \\
\text { Fre. } \%\end{array}$ \\
\hline \multicolumn{4}{|l|}{ Reading } \\
\hline Textbooks & $\begin{array}{l}5 \\
12.2 \%\end{array}$ & $\begin{array}{l}17 \\
41.5 \%\end{array}$ & $\begin{array}{l}19 \\
46.3 \%\end{array}$ \\
\hline Technical articles in journals & $\begin{array}{l}8 \\
19.5 \%\end{array}$ & $\begin{array}{l}14 \\
84.1 \%\end{array}$ & $\begin{array}{l}19 \\
46.3 \%\end{array}$ \\
\hline Manuscripts & $\begin{array}{l}14 \\
34.1 \%\end{array}$ & $\begin{array}{l}17 \\
41.5 \%\end{array}$ & $\begin{array}{l}10 \\
24.4 \%\end{array}$ \\
\hline Texts on the Internet & $\begin{array}{l}4 \\
9.8 \%\end{array}$ & $\begin{array}{l}22 \\
53.7 \%\end{array}$ & $\begin{array}{l}15 \\
36.6 \%\end{array}$ \\
\hline \multicolumn{4}{|l|}{ Writing } \\
\hline Lab reports & $\begin{array}{l}16 \\
39 \%\end{array}$ & $\begin{array}{l}15 \\
36.6 \%\end{array}$ & $\begin{array}{l}10 \\
24.4 \%\end{array}$ \\
\hline assignments & $\begin{array}{l}13 \\
31.7 \%\end{array}$ & $\begin{array}{l}16 \\
39 \% \\
\end{array}$ & $\begin{array}{l}12 \\
29.3 \%\end{array}$ \\
\hline Taking notes in lectures & $\begin{array}{l}14 \\
35 \%\end{array}$ & $\begin{array}{l}18 \\
45 \%\end{array}$ & $\begin{array}{l}8 \\
20 \%\end{array}$ \\
\hline $\begin{array}{l}\text { Answering questions related to the } \\
\text { part of the textbook }\end{array}$ & $\begin{array}{l}16 \\
39 \%\end{array}$ & $\begin{array}{l}13 \\
31.7 \%\end{array}$ & $\begin{array}{l}12 \\
29.3 \%\end{array}$ \\
\hline \multicolumn{4}{|l|}{ Listening and Speaking } \\
\hline Following lectures & $\begin{array}{l}2 \\
4.9 \%\end{array}$ & $\begin{array}{l}17 \\
41.5 \%\end{array}$ & $\begin{array}{l}22 \\
53.7 \%\end{array}$ \\
\hline $\begin{array}{l}\text { Following question/ answer sessions } \\
\text { in class }\end{array}$ & $\begin{array}{l}8 \\
19.5 \%\end{array}$ & $\begin{array}{l}15 \\
36.6 \%\end{array}$ & $\begin{array}{l}18 \\
43.9 \%\end{array}$ \\
\hline Listening to spoken presentations & $\begin{array}{l}3 \\
7.5 \%\end{array}$ & $\begin{array}{l}18 \\
45 \%\end{array}$ & $\begin{array}{l}19 \\
47.5 \%\end{array}$ \\
\hline Participation in discussions & $\begin{array}{l}3 \\
7.3 \%\end{array}$ & $\begin{array}{l}15 \\
36.6 \%\end{array}$ & $\begin{array}{l}23 \\
56.1 \%\end{array}$ \\
\hline Asking questions in class & $\begin{array}{l}8 \\
19.5 \%\end{array}$ & $\begin{array}{l}12 \\
29.3 \%\end{array}$ & $\begin{array}{l}21 \\
51.2 \%\end{array}$ \\
\hline Giving spoken presentations & $\begin{array}{l}7 \\
17.5 \% \\
\end{array}$ & $\begin{array}{l}17 \\
41.5 \%\end{array}$ & $\begin{array}{l}17 \\
41.5 \%\end{array}$ \\
\hline
\end{tabular}

\section{Part 4 of the Questionnaire}

In this part of the questionnaire the students were asked to evaluate their abilities and knowledge of English. Thus, they were asked to self- report what level of English proficiency they had. This was an important question whose answers would be compared with the course content. The items were as follows:

Reading

Writing

Speaking

Listening

Grammar

General vocabulary

Medical vocabulary

As the table 7. Shows they indicated that their medical vocabulary scope (61.9\%) and general vocabulary level $(47.4 \%)$ were not satisfactory. Furthermore $44.7 \%$ stated that their listening skill ability was insufficient. 
TABLE 7.

ABILITIES AND KNOWLEDGE OF ENGLISH OF THE STUDENTS

\begin{tabular}{|l|l|l|l|}
\hline $\begin{array}{l}\text { Abilities and } \\
\text { knowledge of English } \\
\text { of the students }\end{array}$ & $\begin{array}{l}\text { unsatisfactory } \\
\text { Fre. } \\
\text { \% }\end{array}$ & $\begin{array}{l}\text { Satisfactory } \\
\text { Fre. } \\
\%\end{array}$ & $\begin{array}{l}\text { Good } \\
\text { Fre. } \\
\text { \% }\end{array}$ \\
\hline Reading & 7 & 19 & 12 \\
& $18.4 \%$ & $50 \%$ & $31.6 \%$ \\
\hline Writing & 10 & 20 & 8 \\
& $26.3 \%$ & $52.6 \%$ & $21.1 \%$ \\
\hline Speaking & 15 & 12 & 11 \\
& $39.5 \%$ & $31.6 \%$ & $28.9 \%$ \\
\hline Listening & 17 & 14 & 7 \\
& $44.7 \%$ & $36.8 \%$ & $18.4 \%$ \\
\hline Grammar & 15 & 19 & 4 \\
& $39.5 \%$ & $50 \%$ & $10.5 \%$ \\
\hline General vocabulary & 18 & 15 & 5 \\
& $47.4 \%$ & $39.5 \%$ & $13.2 \%$ \\
\hline Medical vocabulary & 13 & 5 & 3 \\
& $61.9 \%$ & $23.8 \%$ & $14.3 \%$ \\
\hline
\end{tabular}

Reading seems to be a better developed ability with $50 \%$ satisfactory and $12 \%$ good percentage. This may be because they had more exposure to reading texts. The following table presents a brief review of what went on in the previous parts.

Although in some cases responses were overlapping, for example in listening $17(44.7 \%)$ respondents claimed their level of listening was unsatisfactory and they needed English very much to be able to understand oral utterances. Moreover, $52.6 \%$ subjects pointed out that they had satisfactory level of written language followed by $26.3 \%$ who believed that they had unsatisfactory level of writing.

In speaking responses were similar. Regarding general and technical vocabulary as can be seen in table 7, these domains were the abilities they needed to develop more than others.

In sum, the figures show that in terms of four main language abilities, respondents needed help to develop to proficient levels in order to reach their goals.

TABLE 8.

DESCRIPTIVE STATISTICS

\begin{tabular}{|l|l|l|l|l|l|}
\hline Items & N & Minimum & Maximum & Mean & Std. Deviation \\
\hline Reading skill & 43 & 1 & 3 & 2.2 & 0.54 \\
\hline Listening skill & 41 & 1 & 3 & 2.35 & 0.58 \\
\hline Speaking skill & 36 & 1 & 3 & 2.1 & 0.70 \\
\hline Writing skill & 35 & 1 & 3 & 2.3 & 0.62 \\
\hline Learning reading skill & 41 & 1 & 3 & 2.2 & 0.45 \\
\hline Learning writing skill & 41 & 1 & 3 & 1.9 & 0.52 \\
\hline Learning speaking and listening skill & 41 & 1 & 3 & 2.4 & 0.51 \\
\hline Evaluation of skills & 38 & 1 & 3 & 1.8 & 0.47 \\
\hline
\end{tabular}

The results of this table indicated perception between students on relative ability in English language skills. As it can be seen, for learning writing skills figures changed almost dramatically. In fact, they stated low level of priority for learning written language $(M=1.9)$. Listening skill( $M=2.35)$ and learning of listening and speaking skills( $M=2.4)$ gained much of attention. This data were particularly important. The stated need to communicate orally may be relevant to medical procedures. In evaluation of their total abilities and considering different skills of English language (M=1.8) more than half of the students believed that they had unsatisfactory knowledge of English. This outcome signals that English language skills in a wider perspective should be addressed and catered for.

\section{DISCUSSION}

As there is an increasing tendency toward more learner- centered approaches and placing the learners themselves in the center of attention in the process of learning, there must be some means of deciding on how the materials can be practical and to what extent the existing materials and courses are thought by the learners as useful. By means of NA which is a process of learning about the present situation of the students in academic contexts and learning about the requirements, important findings were obtained..

The major endeavor throughout this research was made to find out about the type of activities to include in future courses of English and the suitable content by taking account of medical students' point of view.

In the light of findings, it is reasonable to place priority on improving all four basic language skills in general and listening and speaking skills in particular. Furthermore, academic vocabulary development was deemed essential by the learners.More English courses specially designed and geared to students' academic needs are recommended as an urgent need for medical students. Meanwhile, another outcome of the findings was that the English language courses that Medical students currently take do not match their present level and are not satisfactory. 
On the basis of a database of information gained in this study about language needs, perceptions and expectations for English courses new courses can be established to meet the needs of both learners and instructors and to create more practical situation.

This study is regarded as a preliminary process to determine and modify the course content in accordance with the perceived needs.

The results of such analysis can help to increase the likelihood that the English course be related to students' subjects and field of study and their concern as well. In fact, the needs analysis project revealed that students had particular opinions on priorities given to learning of language skills and they were able to assess the importance of related sub skills as related to their academic subjects and interest.

In sum, the elements of analysis lead to the establishment of more fruitful courses leading to more achievement of students in their disciplines.

\section{REFERENCES}

[1] Al-bazzaz, A. A. (1994). The students' low achievement in business English at the College of Business Studies in Kuwait: An analysis of the students' educational and occupational language requirements. University of Sussex (United Kingdom), England.

[2] Al-Busaidi, S. S. (2003). Academic needs of EFL learners in the intensive English language program at Sultan Qaboos University in the Sultanate of Oman. University of Illinois at Urbana-Champaign, United States -- Illinois.

[3] Alderson, J. C. (1990). Testing reading comprehension skills (Part two). Getting students to talk about taking a reading test. (A pilot study). Reading in a Foreign Language, 1, 465-503.

[4] Almulhim, A. M. (2001). An English language needs assessment of Saudi college-of-technology students with respect to a number of business sectors in Saudi Arabia., The University of Mississippi, United States -- Mississippi.

[5] Bosher, S. \& Smalkoski, K. (2002). From needs analysis to curriculum development: Designing a course in health-care communication for immigrant students in the USA. English for Specific Purposes, 21(1), 59-79.

[6] Gillet, B. (1973). Ameliorer la formation professionelle par l'etude du travail. Paris: Les editions d'organisations.

[7] Gorashi, A. K. (1988). The English communication needs of military cadets in Saudi Arabia as perceived by junior officers in the Saudi Army and air difference. Unpublished Ph.D. dissertation, Indiana University.

[8] AI-Kamookh, A. A. (1981). Teaching English as a foreign language in the schools of Saudi Arabia. KS, University of Kansas.

[9] Hutchinson, T., \& Waters, A. (1992). English for specific purposes: A learning centered approach. Cambridge: Cambridge University Press.

[10] Victoria Chan. (2008). "Determining Students' Language Needs in a Tertiary Setting", English Teaching Forum, 39(3), July September P.16.

[11] Widdowson, H.G. (1981). English for Specific Purposes: Criteria for course design. In L. Selinker, E. Tarone \& V. Hanzeli. English For Academic And Technical Purposes: Studies in Honour of Louis Trimble. Rowley, MA: Newbury House. 1-11.

[12] Witkin, R. and J. Altschuld. (1995). Planning and conducting needs assessments. Thousand Oaks, CA, Sage

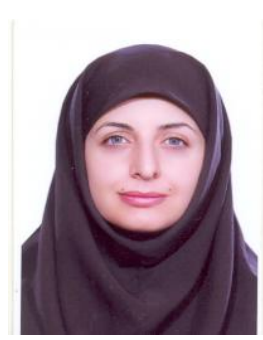

Giti Karimkhanlouei is an Iranian TEFL teacher born in 1978. She obtained her PHD in TEFL from Payame Noor University of Tehran in 2010.

She teaches in topics related to ESP, theories of learning and teaching, development of reading and writing skills, letter writing at Medical University of Zanjan as a faculty member and the other universities of Zanjan as an invited teacher. Her expertise in health and education has led her to serve as a member of the council of the university and as supervisor of theses of the students and a former head of the department of English. She has dedicated her academic life for over 17 years teaching courses of English at Zanjan University of medical sciences. She has published a few books and articles including letter writing published in Zanjan, Iran, Azar Kelk, 2011, common idiomatic expressions and phrases also published in zanjan, Iran, Nikan Ketab, 2008 and a few articles such as comparison of the achievement of medical students in the online course of ESP published in journal of Management and Science, vol 8, No, 1, 2010.Her current research interests are Language teaching and learning with a special focus on students of medicine, e-learning and ESP course evaluation.

Dr. Karimkhanlouei is currently a member of IATEFL and TESOL and has been editor of several books on emerging topics in TEFL 